INGENIERÍA QUÍMICA

\title{
Comportamiento a alta temperatura de transportadores sólidos de oxígeno de base cobre para el proceso "chemical looping combustion"
}

CHEMICAL ENGINEERING

\section{High temperature behaviour of $\mathrm{CuO}$-based oxygen carriers for chemical-looping combustion process}

\author{
Carmen R. Forero§ \\ Escuela de Ingeniería de Recursos Naturales y del Ambiente (EIDENAR), \\ Universidad del Valle, Cali, Colombia \\ $\S$ carmen.forero@correounivalle.edu.co
}

(Recibido: 25 de noviembre 2011- Aceptado: 26 de agosto de 2013)

\begin{abstract}
Resumen
El "Chemical Looping Combustion" (CLC) es una tecnología de combustión con separación inherente del $\mathrm{CO}_{2}$. Para escalar el proceso se necesitan materiales aptos para trabajar a alta temperatura. Se ha probado que los transportadores de base cobre cumplen los requerimientos, sin embargo se ha recomendado su trabajo a temperaturas menores de 1073 $\mathrm{K}$. En este trabajo, se han desarrollado, por impregnación en diferentes soportes, dos transportadores basados en $\mathrm{Cu}$. Se estudió su comportamiento a temperaturas por encima de 1073K en una unidad de CLC de 500 Wth teniendo en cuenta aspectos como: eficiencia de combustión, resistencia al desgaste, aglomeración, mantenimiento de la capacidad de transporte de oxígeno y reactividad. Problemas de aglomeración o desactivación de las partículas no se detectaron con ninguno de los TOs. Fue posible la operación estable durante más de 67 horas sólo con el TO modificado con la adición de $\mathrm{NiO}$ como soporte. Esta es la primera vez que un TO de base cobre, preparado por un método de fabricación comercial, se utiliza a $1173 \mathrm{~K}$ de temperatura en el reactor de reducción (TRR) y $1223 \mathrm{~K}$ en el de oxidación (TRO) y presenta buenas propiedades, abriendo nuevas posibilidades para la aplicación de materiales a base de cobre en los procesos de CLC a escala industrial.
\end{abstract}

Palabras clave: combustión, captura de CO2, cobre, transportadores sólidos de oxígeno.

\begin{abstract}
Chemical-Looping Combustion (CLC) is a combustion technology with inherent $\mathrm{CO}_{2}$ separation. To scale up the CLC process materials suitable to work at high temperatures are needed. Cu-based oxygen carriers had been proved to fulfil the requirements although temperatures lower than $1073 \mathrm{~K}$ has been recommended. In this work, two Cu-based OCs have been developed by impregnation on different supports. The behaviour of the OCs was studied at temperatures above $1073 \mathrm{~K}$ in a CLC continuous unit of $500 \mathrm{Wth}$ taking into account aspects such as combustion efficiency, attrition, agglomeration and maintenance of the oxygen transport capacity and reactivity. Agglomeration or deactivation of the particles was never detected with neither of the oxygen carriers used. At these high temperatures, stable operation for more than $67 \mathrm{~h}$ was feasible only using an $\mathrm{OC}$ with $\gamma \mathrm{A} 12 \mathrm{O} 3$ modified with $\mathrm{NiO}$ addition as support. This is the first time that a Cu-based OC, prepared by a commercial manufacturing method, and used at $1173 \mathrm{~K}$ of fuel reactor temperature (TFR) and $1223 \mathrm{~K}$ of air reactor temperature (TAR) exhibits such a good properties. This result opens new possibilities for the application of $\mathrm{Cu}$-based materials in industrial-scale CLC processes.
\end{abstract}

Keywords: chemical-looping combustion, $\mathrm{CO}_{2}$ capture, copper, oxigen carriers. 


\section{Introduction}

In order to stabilize the $\mathrm{CO}_{2}$ concentration in the atmosphere, several measures must be taken. The Carbon Capture and Storage (CCS) is a process involving the separation of $\mathrm{CO}_{2}$ emitted by industry and energy-related sources, and the storage for its isolation from the atmosphere over the long term. Chemical Looping Combustion (CLC) process has been suggested among the best alternatives to reduce the economic cost of $\mathrm{CO}_{2}$ capture using gaseous fuels (Kerr, 2005) and to increase the efficiency with respect to other $\mathrm{CO}_{2}$ capture process (Kvamsdal et al, 2007). In this process, $\mathrm{CO}_{2}$ is inherently separated from other combustion products, $\mathrm{N}_{2}$ and unused $\mathrm{O}_{2}$, through the use of a solid oxygen carrier (OC) and thus no energy is expended for the separation.

A cornerstone in the successful development of a CLC system is the OC, which is composed of a metal oxide and a support. The $\mathrm{OC}$ besides having a high reactivity with the gas fuel and air during many cycles of reduction-oxidation and full fuel conversion to $\mathrm{CO}_{2}$ and $\mathrm{H}_{2} \mathrm{O}$, must meet other characteristics such as low attrition, no agglomeration during fluidized bed operation, and no carbon deposition. An important aspect of the oxygen-carrier materials is the suitability to be used in continuous CLC units during long periods of time. However, the number of materials tested in this kind of units is limited, Ni-based OC conveyors being the most commonly used, followed by $\mathrm{Cu}$ based OC (Adanéz et al, 2012).

Ni-based OC allows working at high temperatures $(1173-1373 \mathrm{~K})$ and has similar oxygen transfer capacity than $\mathrm{Cu}$-based oxygen carries. Although thermodynamic restrictions make that $\mathrm{CO}$ and $\mathrm{H}_{2}$ are always present in the gas outlet of the fuel reactor. In this sense Adánez et al (2006b) studied the behaviour of different $\mathrm{Ni}-\mathrm{Cu}$ oxygen carriers using alumina as support in a batch fluidized bed working at $1123 \mathrm{~K}$. They found that to have a stable and low attrition rate at high temperature was necessary the existence of a minimum amount of $\mathrm{NiO}$ (about 4 wt. \%) in the oxygen carrier to stabilize the $\mathrm{CuO}$ phase.
Adánez et al (2004) have shown that $\mathrm{Cu}$ based oxygen carriers present high reaction rates and oxygen transfer capacity, and have no thermodynamic restrictions for complete fuel conversion to $\mathrm{CO}_{2}$ and $\mathrm{H}_{2} \mathrm{O}$.

Several $\mathrm{Cu}$-based $\mathrm{OC}$ has been developed using different supports and preparation methods (Adánez et al, 2004; Copeland et al, 2002; Chuang et al, 2008; Johansson et al, 2006; Son et al, 2006). In the "Instituto de Carboquímica" (CSIC) has undertaken several studies using this oxygen carrier (Adánez et al, 2004; de Diego et al, 2004 y 2005; García-Labiano et al, 2007). A $\mathrm{Cu}$-based oxygen carrier support on $\gamma-\mathrm{Al}_{2} \mathrm{O}_{3}$ was finally selected to test its behaviour during $200 \mathrm{~h}$ of continuous operation in a $10 \mathrm{~kW}_{\text {th }}$ CLC prototype using methane as fuel at $1073 \mathrm{~K}$ in both fuel reactor (FR) and air reactor (AR) (Adánez et al, 2006a). Other works showed that the OC can fully convert syngas (Forero et al, 2009) or methane and no special measures should be adopted due to the presence of impurities (Gayán et al, 2010; Forero et al, 2010) when it has been carried out at $1073 \mathrm{~K}$ in a CLC continuous unit of $500 \mathrm{~W}_{\text {th. }}$.

In CLC, oxidation reactor exit temperature is the parameter of paramount significance for plant efficiency. The higher the oxidation temperature, the higher is the turbine inlet temperature (TIT) and hence the higher is the plant efficiency. To scale up the CLC technology information about the high temperature resistance of the oxygen carriers is needed. Agglomeration problems are particularly important working with $\mathrm{Cu}$-based OC (Copeland et al, 2002; Cho et al 2004) due to the low melting temperature of the metallic $\mathrm{Cu}$. There are in the literature very few works dealing with the temperature resistance of the $\mathrm{Cu}$-based OC. de Diego et al (2005) used a $\mathrm{CuO} / \gamma-\mathrm{Al}_{2} \mathrm{O}_{3}$ oxygen carrier at $1223 \mathrm{~K}$ in a batch fluidized bed founding that the behaviour of the oxygen carrier with respect to chemical stability and reactivity was satisfactory, although a small number of cycles were carried out. Very recently, Forero et al (2011) have analysed the behaviour of this oxygen carrier during long-term tests at high temperatures under 
continuous operation in a CLC unit $500 \mathrm{~W}_{\text {th }}$. They found that both $\mathrm{T}_{\mathrm{FR}}$ and $\mathrm{T}_{\mathrm{AR}}$ had a great influence on the resistance to attrition of the particles. Stable operation for more than $60 \mathrm{~h}$ was feasible at $\mathrm{T}_{\mathrm{FR}}$ $=1073 \mathrm{~K}$ and $\mathrm{T}_{\mathrm{AR}}=1173 \mathrm{~K}$ without agglomeration problems or deactivation of the carrier. However, an increase of $100 \mathrm{~K}$ in the AR temperature operation produced a reduction in the particle lifetime from 2700 to $1100 \mathrm{~h}$. It was indicated that a support with a minimized interaction with the metal oxide might be useful to increase the temperature resistance of copper-based oxygen carriers.

In this paper, a Cu-based oxygen carrier was prepared by incipient wet impregnation introducing chemical pre-treatment with $\mathrm{Ni}$ oxide. The influence of the support on the high temperature behaviour of the two $\mathrm{Cu}$-based oxygen carriers was analysed during long-term test in a $500 \mathrm{~W}_{\text {th }}$ CLC unit under continuous operation using methane as fuel and high temperatures both in FR, $1173 \mathrm{~K}$ and in AR, 1223 $\mathrm{K}$. The influence of the support on the combustion efficiency, attrition rate and material agglomeration was investigated. Changes in particles with respect to reactivity, chemical composition and physical characteristic were also analysed.

\section{Experimental}

\subsection{Preparation of oxygen carrier}

The oxygen carriers were prepared by incipient wet impregnation method using $\mathrm{CuO}$ as active phase and $\gamma-\mathrm{Al}_{2} \mathrm{O}_{3}$ and $\mathrm{NiO} / \gamma-\mathrm{Al}_{2} \mathrm{O}_{3}$ as supports.

Supports. Commercial $\gamma-\mathrm{Al}_{2} \mathrm{O}_{3}$ particles (Puralox NWa-155, Sasol Germany GmbH) of 300-500 $\mu \mathrm{m}$ with a density of $1.3 \mathrm{~g} / \mathrm{cm}^{3}$ and a porosity of $55.4 \%$ was used as support to prepared the OC that was named as $\mathrm{Cu}-\gamma \mathrm{Al}$ and as raw material to prepare the $\mathrm{OC}$ named $\mathrm{Cu}-\mathrm{NiAl}$. The chemical pre-treatment consisted in precoating the support with $\mathrm{Ni}\left(\mathrm{NO}_{3}\right)_{2} \cdot 6 \mathrm{H}_{2} \mathrm{O}(>99.5 \%$ Panreac) solution. In order to minimized the environmental problems, the corresponding $\mathrm{NiO}$ content (3 wt.\%) was achieved by applying one impregnation followed by calcination at $823 \mathrm{~K}$ in air atmosphere for $1 \mathrm{~h}$ to decompose the impregnated nitrate.

Oxygen carriers. Cu-based OCs were prepared by the addition of a volume of saturated copper nitrate solution corresponding to the total pore volume of the support particles. The aqueous solution was slowly added to the support particles, with thorough stirring at room temperature, followed by calcination at $823 \mathrm{~K}$, in air atmosphere for $30 \mathrm{~min}$ in a muffle oven to decompose the impregnated copper nitrate into copper oxide. Finally, the oxygen carrier was stabilized in air atmosphere for 1 hour at $1123 \mathrm{~K}$. Fresh and after-used samples of the oxygen carriers were physically and chemically characterized by several techniques. The main characteristics of the $\mathrm{Cu}$-based oxygen carriers are showed in Table 1.

\subsection{CLC continuous unit of $500 \mathrm{Wth}$}

Fig. 1 show a schematic diagram of the reactor system, located at "Instituto de Carboquímica" (CSIC). The facility used in this study is a CLC continuous unit of 500 Wth composed of two interconnected fluidized bed reactors. Detailed information about the prototype and operating procedure used can be found elsewhere (Forero et al, 2009).

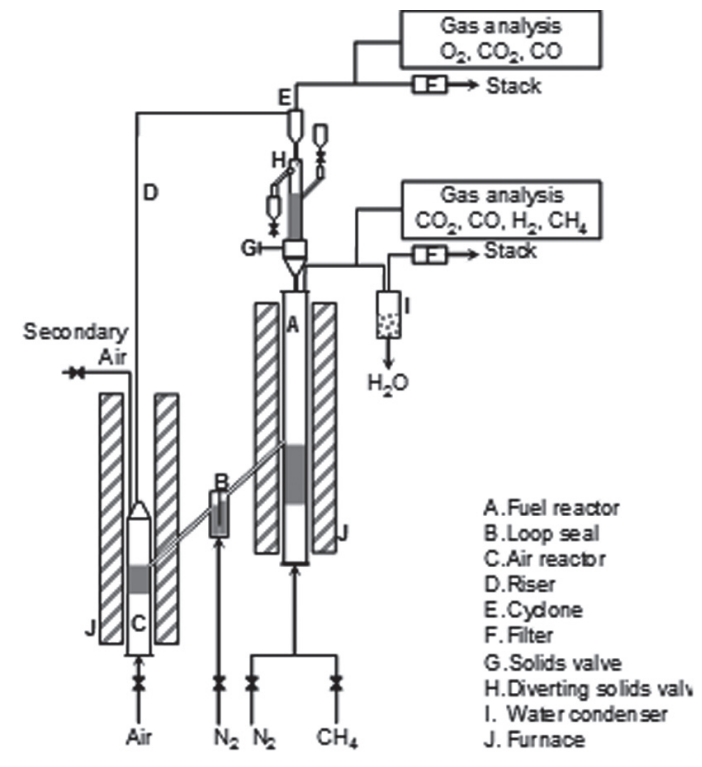

Figure 1. Schematic diagram of the Chemical-Looping Combustion continuous unit of 500 Wth. 
Table 1. Properties of the fresh and used Cu-based OCs.

\begin{tabular}{|c|c|c|c|c|}
\hline & \multicolumn{2}{|c|}{$\mathrm{Cu}-\gamma \mathrm{Al}$} & \multicolumn{2}{|c|}{ Cu-NiAl } \\
\hline & Fresh & Used-29h & Fresh & Used-67h \\
\hline $\mathrm{CuO}$ content, $\mathrm{xCuO}(\mathrm{wt} \%)$ & 14.2 & 13 & 12.8 & 10.6 \\
\hline Oxygen transport capacity Ro,OC (\%) & 2.86 & 2.62 & $2.57^{\mathrm{a}}$ & $2.13^{\mathrm{a}}$ \\
\hline Porosity $(\%)$ & 50 & 58 & 54 & 45 \\
\hline Specific surface area BET $(\mathrm{m} 2 / \mathrm{g})$ & 91.3 & 6.8 & 91.4 & 4.9 \\
\hline Bulk density (g/cm3) & 1.7 & 1.5 & 1.6 & 2.1 \\
\hline Crushing strength ( N) & 2.9 & 0.6 & 3.1 & 2.0 \\
\hline Crystalline phases, particles from AR & $\begin{array}{c}\mathrm{CuO} \\
\mathrm{CuAl} 2 \mathrm{O} 4 \\
\gamma \mathrm{Al} 2 \mathrm{O} 3\end{array}$ & $\begin{array}{c}\mathrm{CuO} \\
\mathrm{CuAl}_{2} \mathrm{O}_{4} \\
\alpha \mathrm{Al}_{2} \mathrm{O}_{3}\end{array}$ & $\begin{array}{c}\mathrm{CuO} \\
\mathrm{CuAl}_{2} \mathrm{O}_{4} \\
\mathrm{NiAl}_{2} \mathrm{O}_{4}^{\mathrm{b}, \mathrm{c}} \\
\gamma \mathrm{Al}_{2} \mathrm{O}_{3}\end{array}$ & $\begin{array}{c}\mathrm{CuO} \\
\mathrm{CuAl} 2 \mathrm{O} 4 \\
\mathrm{NiAl}_{2} \mathrm{O}_{4}^{\mathrm{b}, \mathrm{c}} \\
\alpha \mathrm{Al}_{2} \mathrm{O}_{3}\end{array}$ \\
\hline Crystalline phases, particles from FR filter & & $\begin{array}{c}\mathrm{Cu} \\
\mathrm{CuO} \\
\mathrm{Cu}_{2} \mathrm{O} \\
\mathrm{CuAl}_{2} \mathrm{O}_{4} \\
\alpha_{2} \mathrm{O}_{3}\end{array}$ & & $\begin{array}{c}\mathrm{Cu} \\
\mathrm{CuO} \\
\mathrm{Cu}_{2} \mathrm{O} \\
\mathrm{CuAl}_{2} \mathrm{O}_{4} \\
\alpha \mathrm{Al}_{2} \mathrm{O}_{3}\end{array}$ \\
\hline Crystalline phases, particles from AR filter & & $\begin{array}{c}\mathrm{CuO} \\
\mathrm{CuAl}_{2} \mathrm{O}_{4} \\
\mathrm{CuAlO}_{2} \\
\mathrm{\alpha Al}_{2} \mathrm{O}_{3}\end{array}$ & & $\begin{array}{c}\mathrm{CuO} \\
\mathrm{CuAl}_{2} \mathrm{O}_{4} \\
\mathrm{NiAl}_{2} \mathrm{O}_{4}^{\mathrm{b}, \mathrm{c}} \\
\mathrm{\alpha Al}_{2} \mathrm{O}_{3}\end{array}$ \\
\hline
\end{tabular}

${ }^{a} \mathrm{NiO}$ as inert. ${ }^{\mathrm{b}}$ Minor amount ${ }^{\mathrm{c}}$ Identified by TPR

The solid inventory in the plant was about of 1.2 $\mathrm{kg}$ of OC. The fuel gas in the FR was methane diluted in nitrogen and air was used as fluidizing gas in the AR. The inlet gas flow and gas velocity used were the same used in a previous work (Forero et al, 2011).

\subsection{Combustion tests}

Long-term CLC tests under different operating conditions were carried out at high temperature both in the FR $\left(\mathrm{T}_{\mathrm{FR}}=1173 \mathrm{~K}\right)$ as in the $\mathrm{AR}\left(\mathrm{T}_{\mathrm{AR}}\right.$ $=1223 \mathrm{~K}$ ) using $\mathrm{Cu}$-based oxygen carriers and methane as fuel. FR and AR temperatures were kept constant during overall operation for each test using the same batch of oxygen carrier particles. The duration of the tests were fixed to be long enough to analyze the effect of temperature on the physical and chemical characteristics of the particles and make a reliable estimation of the particle lifetime at those conditions. The tests with $\mathrm{Cu}-\gamma \mathrm{Al}$ should be early stopped due to operational problems caused by the amount of fines generated. More than $67 \mathrm{~h}$ in hot conditions were carried out in tests with $\mathrm{Cu}-\mathrm{NiAl}$ where operation of the plant was possible.

The oxygen carrier to fuel ratio $(\phi)$ was defined by Ec. (1), where $\mathrm{F}_{\mathrm{CuO}}$ is the molar flow rate of the copper oxide and $\mathrm{F}_{\mathrm{CH}_{4}}$ is the inlet molar flow rate 


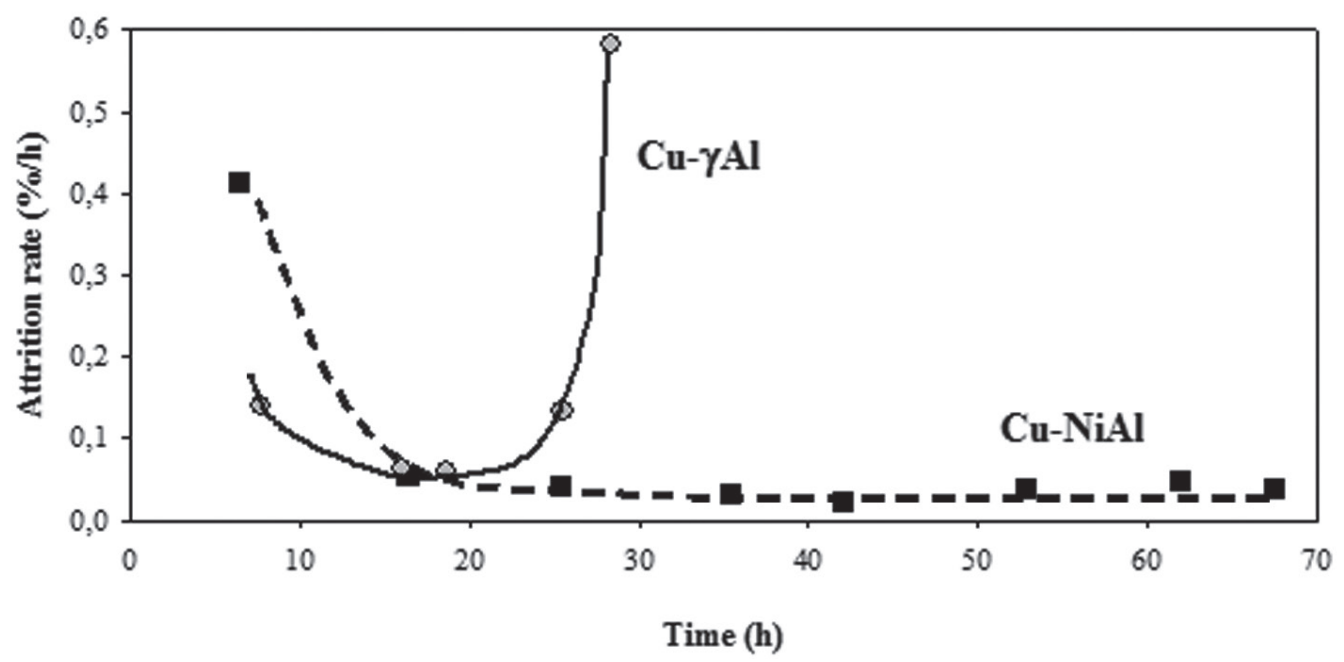

Figure 2. Effect of the oxygen carrier to fuel ratio on the combustion efficiency of two Cu-based OCs. $T_{F R}=1173 \mathrm{~K}, T_{T A R}=1223 \mathrm{~K} . \mathrm{O} \mathrm{Cu}-\gamma \mathrm{Al}$. Cu-NiAl. Values indicate the solids inventory per $\mathrm{MW}, \mathrm{m}^{*} \mathrm{FR}$ ( $\mathrm{kg} / \mathrm{MWth})$.

of the $\mathrm{CH}_{4}$ in the FR. A value of $\phi=1$ corresponds to the stoichiometric $\mathrm{CuO}$ amount needed for a full conversion of the fuel to $\mathrm{CO}_{2}$ and $\mathrm{H}_{2} \mathrm{O}$ :

$$
\phi=\frac{\mathrm{FCuO}}{4 \mathrm{~F}_{\mathrm{CH}_{4}}}
$$

The effect of the oxygen carrier to fuel ratio, $\phi$ on the combustion efficiency was carried out varying the fuel concentration. It must be pointed out, that although during the first $10 \mathrm{~h}$ of operation the experiments were carried out at different power inputs. The remaining operation time was carried out at constant operating conditions corresponding to those of complete combustion of methane.

The combustion efficiency (Ec. (2)) was defined as the ratio of the oxygen consumed by the gas leaving the FR to that consumed by the gas when the fuel is completely burnt to $\mathrm{CO}_{2}$ and $\mathrm{H}_{2} \mathrm{O}$.

$$
\eta_{\mathrm{c}}=\frac{\left(2 \mathrm{x}_{\mathrm{CO}_{2}}+\mathrm{x}_{\mathrm{CO}^{+}}+\mathrm{x}_{\mathrm{H}_{2} \mathrm{O}}\right)_{\text {out }} \mathrm{F}_{\text {out }}}{\left(4 \mathrm{x}_{\mathrm{CH}_{4}}\right)_{\text {in }} \mathrm{F}_{\text {in }}} 100
$$

where $F_{\text {in }}$ is the molar flow of the inlet gas stream, $\mathrm{F}_{\text {out }}$ is the molar flow of the outlet gas stream, and $\mathrm{x}_{\mathrm{i}}$ is the molar fraction of the gas $i$ corresponding to the inlet or outlet.
Attrition and/or fragmentation of particles were analyzed during continuous long-term tests. Attrition rate $(A)$, was defined by Ec. (3), where $\mathrm{w}_{f}$ is the weight of elutriated particles $<40 \mu \mathrm{m}$ during a period of time, $w_{t}$ is the weight of total solids inventory and $\Delta \mathrm{t}$ is a period of time during the particles were collected

$$
A=\frac{w_{f}}{w_{t} \cdot \Delta t} 100
$$

\section{Results and discussion}

The results are presented analyzing the influence of the oxygen carrier to fuel ratio on the combustion efficiency and on the behavior of OCs.

\subsection{Combustion efficiency}

During the first $10 \mathrm{~h}$ of operation the experiments were carried out varying the fuel flow but keeping the solids circulation rate approximately constant $(\approx 8.5 \mathrm{~kg} / \mathrm{h})$. Fig. 2 shows the effect of the oxygen carrier to fuel ratio, $\phi$, on the combustion efficiency when the power input changed in the range of 500-780 Wth at $\mathrm{T}_{\mathrm{FR}}=1173 \mathrm{~K}$ and $\mathrm{T}_{\mathrm{AR}}=$ $1223 \mathrm{~K}$ with two OCs. Therefore, as the fuel flow increased, the $\phi$ ratio and the solids inventory in the 
FR per $\mathrm{MW}_{\text {th }}$ of fuel gas, $\mathrm{m}_{\mathrm{FR}}^{*}$, decreased. In both cases, $280 \mathrm{~kg} / \mathrm{MW}_{\text {th }}$ to achieved full conversion of methane is necessary at low $\phi$ values $(\phi>1.2)$. This result showed the high reactivity of the OCs, independently of the support used.

\subsection{Oxygen carrier behaviour}

Besides full combustion, other aspects like agglomeration, attrition, reactivity, and oxygen carrier properties should be considered to evaluate the behaviour of the different oxygen carriers during tests at high temperature. However, in spite of that the high operation temperatures used in the experiments, agglomeration or defluidization of the reactors (FR or AR) were never detected. These results are very relevant for the future use of $\mathrm{Cu}$-based materials as oxygen carrier for CLC technology taking into account the high temperatures used in the tests $\left(\mathrm{T}_{\mathrm{FR}}=1173 \mathrm{~K}\right.$, and $\mathrm{T}_{\mathrm{AR}}=1223 \mathrm{~K}$ ).

\subsubsection{Attrition rates}

Attrition rate is a useful measure to estimate the lifetime of particles. Fig. 3 shows the evolution with time of the attrition rate during the operation in the CLC continuous unit of $500 \mathrm{~W}_{\text {th }}$ with both OCs. The generation of fine particles was high at the beginning of the operation for two OCs. Later, the attrition rate due to the internal changes produced in the particles by the successive reduction and oxidation cycles during operation presented different behaviour depending on the OC.

The $\mathrm{Cu}-\gamma \mathrm{Al}$ presented an abrupt increase of the generation of fines after $20 \mathrm{~h}$ of operation

resembling that the particles had chunked. The amount of fines was too high and forced to stop operation in the plant. With $\mathrm{Cu}-\mathrm{NiAl} \mathrm{OC}$ the system was running satisfactorily around $67 \mathrm{~h}$, with a stable and low value of the attrition rate $(0.04 \%)$, giving an estimation of the particle lifetime around $2700 \mathrm{~h}$. This value is comparable to the one calculated for a $\mathrm{CuO}-\gamma \mathrm{Al}_{2} \mathrm{O}_{3}$ oxygen carrier during $100 \mathrm{~h}$ of operation in a $10 \mathrm{~kW}$ CLC pilot plant, although working at lower temperatures $(1073 \mathrm{~K})$ in both reactors (de Diego et al, 2007). Therefore, an increase of $100 \mathrm{~K}$ in the $\mathrm{T}_{\mathrm{FR}}$ and $150 \mathrm{~K}$ in $\mathrm{T}_{\mathrm{AR}}$ can be done without a detrimental effect on the particle lifetime when chemical pre-treatment was used in the

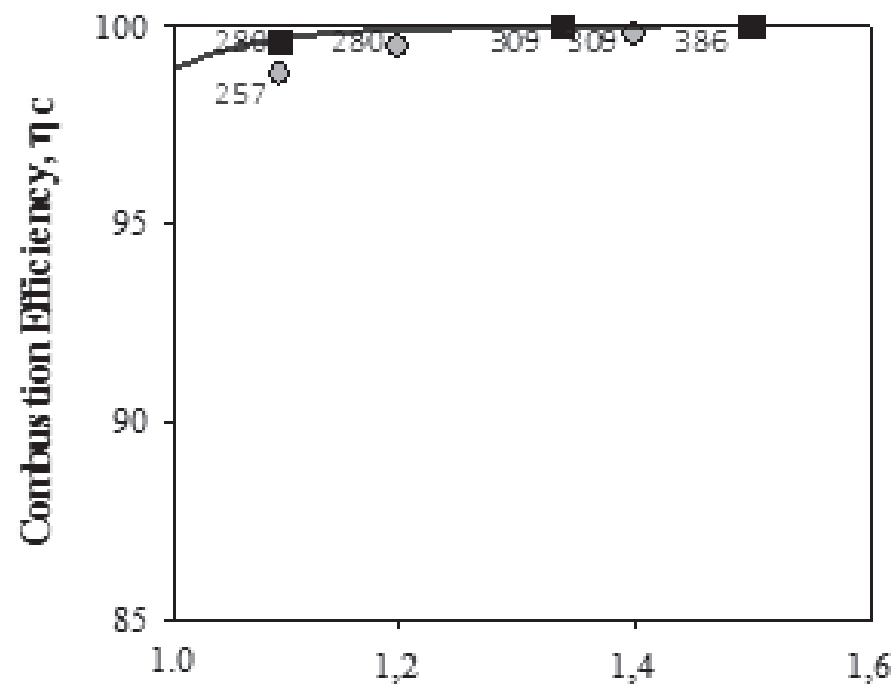

Oxygen Carrier toFuel Ratio, $\phi$

Figure 3. Attrition rates vs. time of two Cu-based OCs. TFR $=1173 \mathrm{~K}$,

$$
T A R=1223 \mathrm{~K} . \mathrm{OCu}-\gamma \mathrm{Al} \text {. } \mathbf{C u}-\mathrm{NiAl}
$$



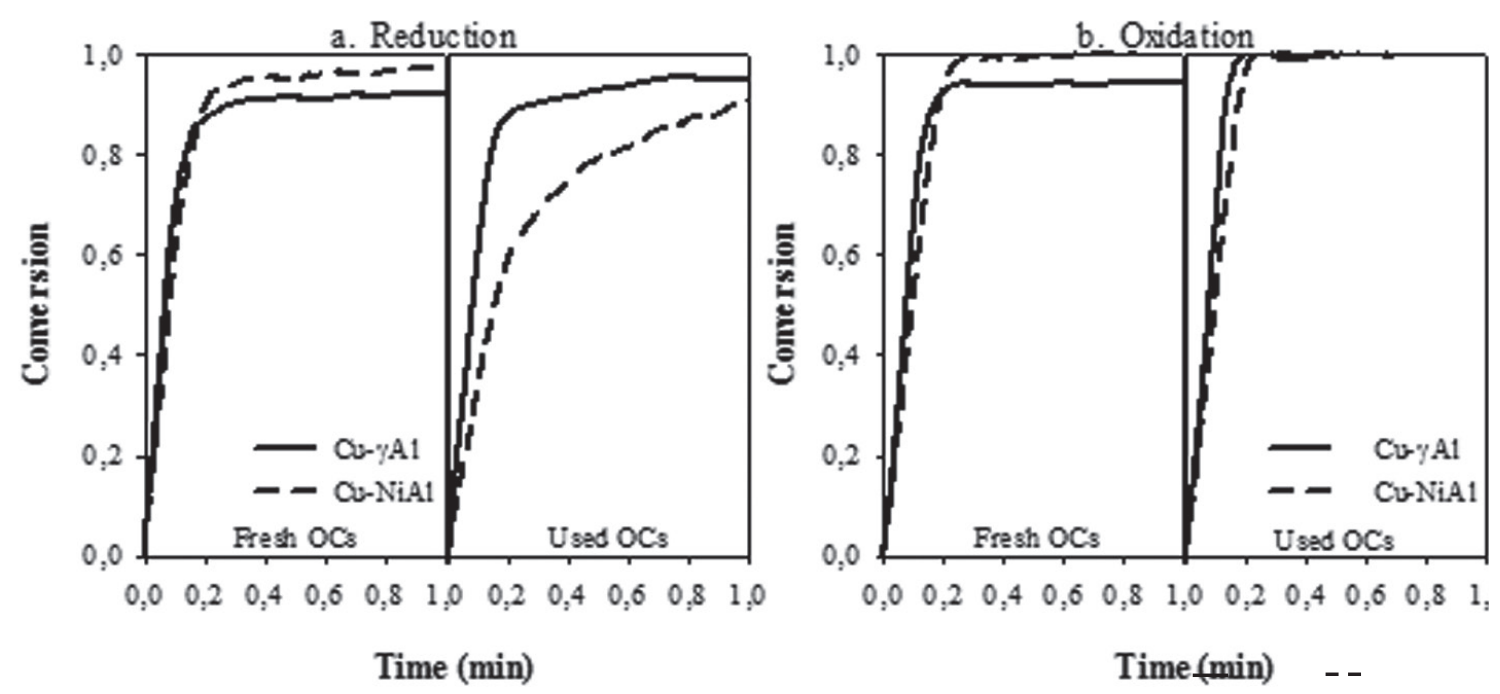

Figure 4. Solid conversion vs. time curves in TGA for a) reduction and b) oxidation reactions of fresh and after-used $\mathrm{Cu}$ based OCs particles. Reduction: $\mathrm{CH} 4=15 \%, \mathrm{H} 2 \mathrm{O}=20 \%, \mathrm{~N} 2=65 \%$. Oxidation: air. T=1073 K. Cu- $\gamma \mathrm{Al} . \mathrm{Cu}-\mathrm{NiAl}$.

preparation of the modified support to obtain $\mathrm{Cu}-\mathrm{NiAl} \mathrm{OC}$.

\subsubsection{Reactivity}

The $\mathrm{CuO}$ content $\left(x_{\mathrm{CuO}}\right)$ reduction measured for OCs during the operation in the CLC plant (see Table 1) produced a decrease in the oxygen transport capacity $\left(\mathrm{R}_{\mathrm{O}, \mathrm{OC}}\right)$ of the $\mathrm{OCs}$ and might be changes in the reactivity. However, in spite of the reduction in the oxygen transport capacity, full combustion efficiency for $\phi>1.2$ were always reached in the CLC continuous unit during operation. Fig. 4 shows the conversion curves obtained in TGA at $1073 \mathrm{~K}$, using a mixture of $15 \mathrm{vol} \% \mathrm{CH} 4,20 \mathrm{vol} \%$ $\mathrm{H} 2 \mathrm{O}$, and 65 vol \% N2 in the fresh oxygen carrier and in samples taken at the end of the different tests, corresponding also to different operation times.

The conversion level of the oxygen carrier was calculated for the reduction and oxidation reactions as:

$$
\begin{gathered}
X_{r e d}=\frac{m_{\alpha}-m}{m_{w} R_{o, O} x_{C u O}} \\
X_{\alpha}=1-\frac{m_{w}-m}{m_{w} R_{o, O} x_{C u O}}
\end{gathered}
$$

where $m$ is the actual mass of sample, $m_{o x}$ is the mass of the sample fully oxidized.

After-used $\mathrm{Cu}-\gamma \mathrm{Al}$ maintained their high reactivity. $\mathrm{Cu}-\mathrm{NiAl}$ OC presented a decrease in the reduction reactivity; which is attributed mainly to the loss of the $\mathrm{CuO}$ content (see Table 1). Although it could be due to the presence of $\mathrm{NiAl}_{2} \mathrm{O}_{4}$, whose reactivity is lower than that of $\mathrm{NiO}$ (Adánez et al, 2009; Dueso et al, 2010, Dueso et al, 2012) is not clearly noticed an increase in this compound, as discussed later. However, the used particles were fully reduced below $60 \mathrm{~s}$, and showed very high oxidation reactivities, indicating that particles maintain its high reactivity after operation at high temperatures in the CLC unit.

\subsubsection{Characterization of $\mathrm{Cu}$-based oxygen carriers}

To analyze the results obtained regarding the effect of the support on the behaviour of the particles at high temperature, physical and chemical properties of the oxygen carrier particles coming from the $\mathrm{AR}$, and from fines recovered in the filters at the FR and AR outlet streams were compared to those of fresh particles. Table 1 shows the main properties of the different materials after used in the CLC continuous unit of $500 \mathrm{~W}_{\text {th }}$ during long-term tests. 


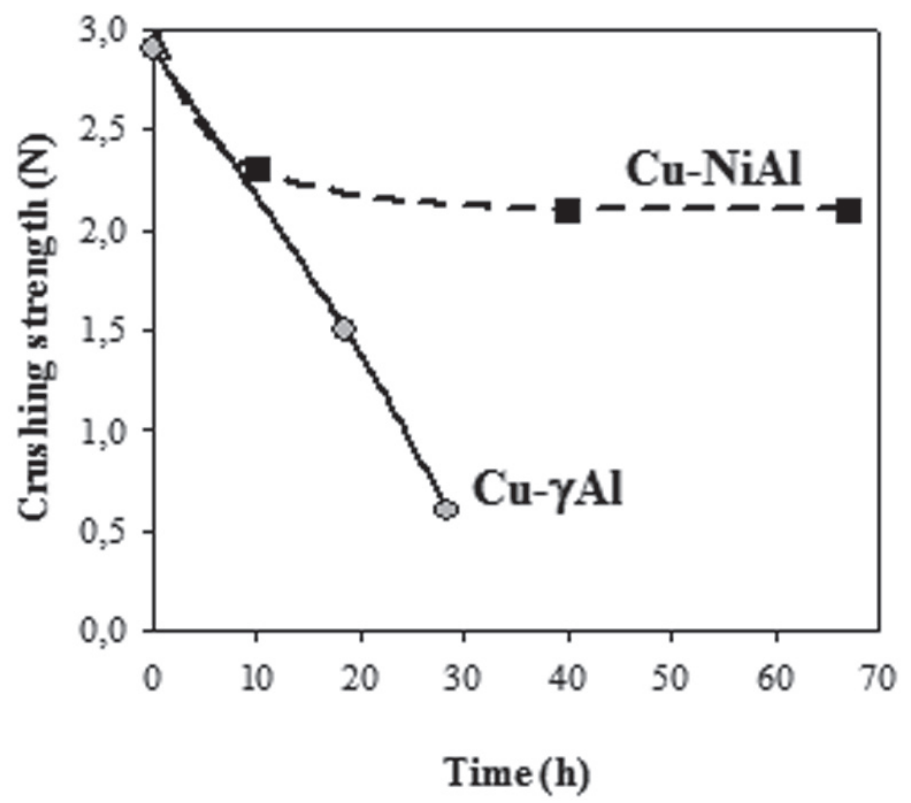

Figure 5. Crushing strength evolution of the two Cu-based OCs. ○ $\mathrm{Cu}-\gamma \mathrm{Al}$. $\square \mathrm{Cu}-\mathrm{NiAl}$.

Porosity. The chemical pre-treatment of the $\mathrm{\gamma Al}_{2} \mathrm{O}_{3}$ to produce $\mathrm{NiOAl}_{2} \mathrm{O}_{4}(6 \%)$ hardly affected the pore size distribution of $\gamma \mathrm{Al}_{2} \mathrm{O}_{3}$. At the end of the tests, the pore size distribution of the samples had changed considerably with respect to the fresh particles with the full disappearance of $12 \mathrm{~nm}$ pores. Changes in porosity are related with changes in the oxygen carrier bulk density, consequently the $\mathrm{Cu}-\gamma \mathrm{Al}$ presented a minor decrease of this characteristic and $\mathrm{Cu}-\mathrm{NiAl}$ presented an increased.

Specific surface area. The BET specific surface area of two used OCs decreased due to that thermal sintering occurred inside the particles due to the high operational temperatures used in FR and AR.

Crushing strength. Fig. 5 shows the effect of the support on the crushing strength at different operation times from samples extracted from the AR. Cu- $\gamma \mathrm{Al}$ OC presented a fast and important decrease of this property, with a value of less than $1 \mathrm{~N}$ after $25 \mathrm{~h}$ of operation. However, $\mathrm{Cu}-\mathrm{NiAl} \mathrm{OC}$ had a smooth decrease, with a value of $2.1 \mathrm{~N}$ at the end of operation at high temperature. Therefore, the initial values of the crushing strength of the OC particles are not a suitable characteristic to evaluate the particle lifetime in the process.
Crystalline phases. Powder XRD patterns of the fresh carriers, shown in Table 1, revealed the presence of $\mathrm{CuO}$, and $\gamma-\mathrm{Al}_{2} \mathrm{O}_{3}$ as the main crystalline phases for fresh OCs. The interaction of copper with the support is revealed through the formation of copper aluminate, $\mathrm{CuAl}_{2} \mathrm{O}_{4} \mathrm{NiAl}_{2} \mathrm{O}_{4}$ are also present in the corresponding OCs.

Powder XRD analysis of samples extracted from the AR and collected at the outlet of the AR and FR streams at the end of each long-term test are also showed in Table 1. The powder XRD patterns of the used samples revealed the transformation of the $\gamma-\mathrm{Al} 2 \mathrm{O} 3$ to $\alpha-\mathrm{Al}_{2} \mathrm{O}_{3}$ in both OCs as a most stable phase at high temperature, explaining the observed evolution of the textural properties of the used particles. A new copper aluminate, $\mathrm{CuAlO}_{2}$, was detected in used particles of $\mathrm{Cu}-\gamma \mathrm{Al}$. Reduced $\mathrm{CuO}$ phases, $\mathrm{Cu}_{2} \mathrm{O}$ and $\mathrm{Cu}$, were detected in all the samples collected in the filter at the outlet of the FR. Oxidized compounds of copper $(\mathrm{CuO}$ and copper aluminates) were only found in the samples coming from the $\mathrm{AR}$ and from the $\mathrm{AR}$ filter, verifying that the oxygen carrier reached always full oxidation state in the AR. As it can be seen, similar crystallite compounds to the fresh OCs particles were detected in the corresponding used samples. This fact 
a) Fresh

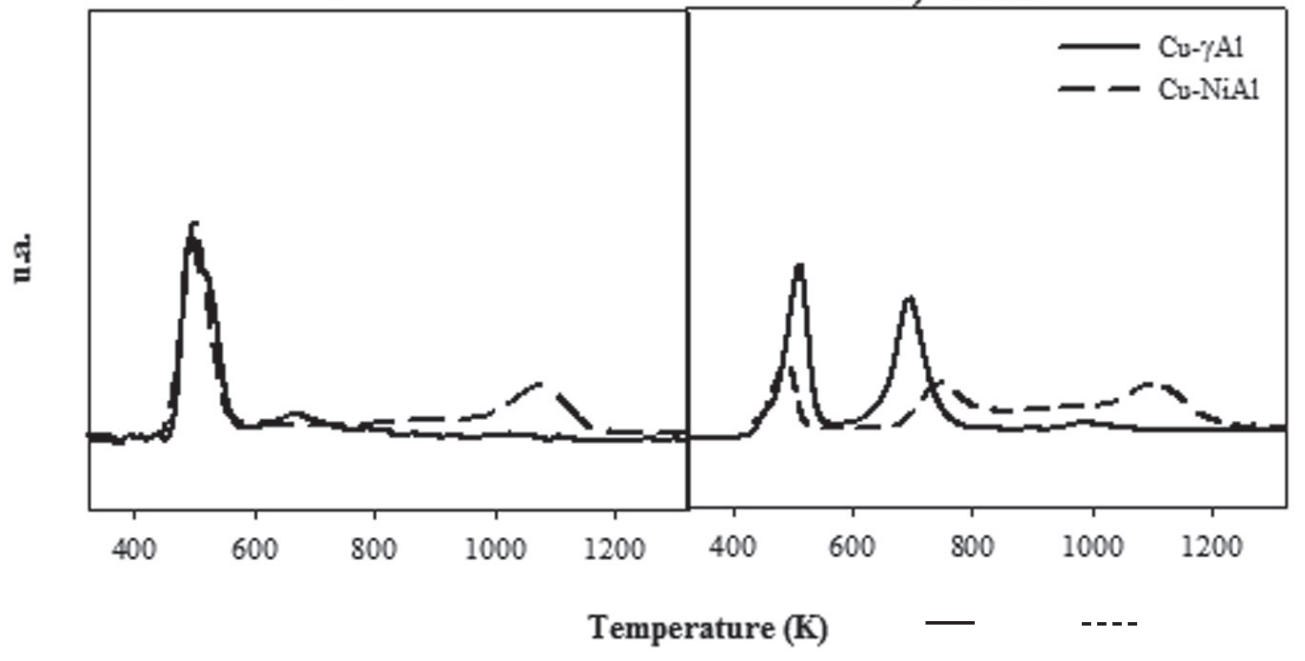

Figure 6. H2-TPR profiles of the fresh and after-used Cu-based OCs. Cu- $\gamma \mathrm{Al} . \quad \mathrm{Cu}$-NiAl.

revealed that the attrited material is composed both of copper compounds and of support. A possible cause of the low attrition found in $\mathrm{Cu}-\mathrm{NiAl} \mathrm{OC}$ could be the absence of a new phase $\left(\mathrm{CuAlO}_{2}\right)$ found in used samples when $\mathrm{Cu}-\gamma \mathrm{Al} \mathrm{OC}$ is used as found in previous work (Forero et al, 2011).

Temperature-programmed reduction. The identification of the formation of $\mathrm{NiAl}_{2} \mathrm{O}_{4}$ in the fresh and after used $\mathrm{Cu}-\mathrm{NiAl}$ particles should be carried out by TPR analysis due to XRD technique only detects crystalline phases with content higher of $5 \%$. Therefore, TPR analyses of fresh and used particles of the different OCs were performed to determine the reducible species and the temperature at which the reduction of these species occurs. Fig. 6 shows the different TPR profiles measured for the fresh and after used OCs particles. The TPR spectra showed several $\mathrm{H}_{2}$ consumption peaks. The peak in the temperature range of $473-573 \mathrm{~K}$ is attributed to the reduction of dispersed and bulk $\mathrm{CuO}$ species (Luo et al, 2005). The peak in the temperature range of $623-773 \mathrm{~K}$ is attributed to the reduction of $\mathrm{CuAl}_{2} \mathrm{O}_{4}$ (Luo et al, 2005). The peak in the temperature range of $650-900 \mathrm{~K}$ is attributed to the reduction of $\mathrm{Ni}^{2+}$ in the free $\mathrm{NiO}$ phase (Dueso et al, 2010). The reduction of $\mathrm{CuAlO}_{2}$ phase has a high temperature peak around $1033 \mathrm{~K}$ (Artizzu et al, 1999). The high temperature peak at 1073-
$1273 \mathrm{~K}$ is associated with the reduction of $\mathrm{Ni}^{2+}$ in $\mathrm{NiAl}_{2} \mathrm{O}_{4}$ (Li y Chen, 1995).

Similar profiles were measured for the different OCs both fresh and after used. Fresh OCs presented a main peak corresponding to the reduction of $\mathrm{CuO}$ compound. After used OCs presented two main peaks attributed to $\mathrm{CuO}$ and $\mathrm{CuAl}_{2} \mathrm{O}_{4}$ reductions and a minor peak around $973 \mathrm{~K}$ corresponding to $\mathrm{CuAlO}_{2}$ phase (Artizzu et al, 1999). In this sense, TPR profiles are consistent with XRD data which indicate the presence of both $\mathrm{CuO}$ and $\mathrm{CuAl}_{2} \mathrm{O}_{4}$ as main phases in most of the samples and a minor existence of $\mathrm{CuAlO}_{2}$ compound. It is worth noting that these three compounds are highly reactive. The presence of $\mathrm{NiAl}_{2} \mathrm{O}_{4}$ in the $\mathrm{Cu}-\mathrm{NiAl}$ OC was revealed by the high temperature peak characteristic of the reduction of this phase in both fresh and after-used particles. Although, in afterused particles a peak between 650-900 K appears indicating the presence of $\mathrm{NiO}$, which is more reactive than $\mathrm{NiAl}_{2} \mathrm{O}_{4}$ (Adanéz et al, 2009), is not consistent with that observe in reactivity. Possibly the amounts are very low that not have influence in reactivity of this oxygen carrier. The chemical pretreatment of the $\gamma \mathrm{Al}_{2} \mathrm{O}_{3}$ with $\mathrm{NiO}$ to form partially the stable $\mathrm{NiAl}_{2} \mathrm{O}_{4}$ structure in the $\mathrm{Cu}-\mathrm{NiAl}$ OC could help to increase the temperature resistance of the particles and to reduce the attrition rate of this OC. 
According to the experimental work herein carried out, the $\mathrm{Cu}$-based OCs developed can be used at $\mathrm{T}_{\mathrm{FR}}=1173 \mathrm{~K}$ and $\mathrm{T}_{\mathrm{AR}}=1223 \mathrm{~K}$ without agglomeration problems or deactivation of the carrier with a complete combustion of the fuel working at oxygen carrier to fuel ratios above $\approx 1.2$, which corresponds to a solid circulation rate of $\approx 4.0 \mathrm{~kg} \mathrm{~s}^{-1}$ per $\mathrm{MW}_{\text {th }}$. Being the maximum circulation rate of solids about $16 \mathrm{~kg} \mathrm{~s}^{-1}$ per $\mathrm{MW}_{\text {th }}$ 41 , the optimal operation conditions $(\phi>1.2)$ could be easily reached in an industrial CLC system using $\mathrm{Cu}$-based oxygen carriers.

The $\mathrm{OC}$ prepared using $\mathrm{NiO} / \gamma \mathrm{Al}_{2} \mathrm{O}_{3}$ as support can be used at $\mathrm{T}_{\mathrm{FR}}=1173 \mathrm{~K}$ and $\mathrm{T}_{\mathrm{AR}}=1223 \mathrm{~K}$ without any operational problems. Operational cost related with the oxygen carrier renovation should be taking into account. High attrition rates will decrease the particle lifetime increasing the cost of the CLC process. It can be seen that $\mathrm{Cu}-\mathrm{NiAl} \mathrm{OC}$ had a low attrition rate and the highest particle lifetime (2700 h) even working at high temperatures. As can be inferred from these results, an increase of $100 \mathrm{~K}$ in the $\mathrm{T}_{\mathrm{FR}}$ and $150 \mathrm{~K}$ in $\mathrm{T}_{\mathrm{AR}}$ can be done with the same replacement of the material that working at $1073 \mathrm{~K}$ in both reactors with the $\mathrm{CuO}-\gamma \mathrm{Al}_{2} \mathrm{O}_{3} \mathrm{OC}$.

In addition, $\mathrm{Cu}$-based $\mathrm{OC}$ had been rejected as best candidate for the CLC process due to its agglomeration problems and its restricted operational temperatures. The results found in this work show that $\mathrm{Cu}$-based $\mathrm{OC}$ can be used at higher temperatures than referred before without any operational problems. This is the first time that a $\mathrm{Cu}-$ based OC, prepared by a commercial manufacturing method, and used at $1173 \mathrm{~K}$ in the FR and $1223 \mathrm{~K}$ in the AR exhibits such a good properties (high reactivity together with high mechanical durability and absence of agglomeration). This result opens new possibilities for the application of $\mathrm{Cu}$-based materials in industrial-scale CLC processes.

Nevertheless, the OC developed in this work with high temperature resistance contains a low amount of $\mathrm{NiO}$ (3 wt.\%). Some drawbacks are derived from this $\mathrm{NiO}$ content, an expensive metal oxide with important health and environmental hazards.
By the one hand, the use of $\mathrm{NiO}$, more expensive than $\mathrm{CuO}$, would increase the costs of the oxygen carrier manufacture. By the other hand, it would be necessary a waste management analysis of this $\mathrm{OC}$ due to the environmental risks of Ni. Although in a previous work (García-Labiano et al, 2007), it was found that the solid waste generated in a CLC process working with $\mathrm{CuO}-\gamma \mathrm{Al}_{2} \mathrm{O}_{3} \mathrm{OC}$ can be classified as a stable nonreactive hazardous waste acceptable at landfills for nonhazardous wastes, the presence of a small fraction of $\mathrm{NiO}$ or $\mathrm{NiAl}_{2} \mathrm{O}_{4}$ in the residue would required more detailed studies.

\section{Conclusions}

Two Cu-based oxygen carriers have been developed by impregnation on different supports $\left(\gamma \mathrm{Al}_{2} \mathrm{O}_{3}\right.$ and $\left.\mathrm{NiO} / \gamma \mathrm{Al}_{2} \mathrm{O}_{3}\right)$. The supports were prepared by chemical modifications of commercial $\gamma \mathrm{Al}_{2} \mathrm{O}_{3}$ with the aim of reduce the interaction with the metal oxide. The influence of the support on the high temperature behaviour of the $\mathrm{Cu}$-based oxygen carriers was analyzed during long-term test in a $500 \mathrm{~W}_{\text {th }}$ CLC unit under continuous operation using methane as fuel and high temperatures both in FR, $1173 \mathrm{~K}$ and in AR, $1223 \mathrm{~K}$. The behaviour of the OCs on the process performance was evaluated taking into account important aspects such as: combustion efficiency, resistance to attrition, fluidization behaviour (no presence of agglomeration) and maintenance of the oxygencarrying capacity and reactivity.

Complete fuel combustion was reached at $\phi>$ 1.2 with both OCs. Moreover, in spite of the high temperatures used in the tests, agglomeration or defluidization of the bed were never detected in reducing or oxidation conditions with any of the OCs used in this work.

$\mathrm{Cu}-\gamma \mathrm{Al}$ OC had an abrupt increase of the attrition rate resembling that the particles had chunked. $\mathrm{Cu}-$ $\mathrm{NiAl} \mathrm{OC}$ had a low and stable attrition rate after 67 $\mathrm{h}$ of operation at high temperature, maintaining its structural integrity and original homogeneity. The presence of $\mathrm{NiAl}_{2} \mathrm{O}_{4}$ in the $\mathrm{Cu}-\mathrm{NiAl}$ OC structure could help to avoid the sintering process of $\mathrm{Cu}$ 
inside the particles and to reduce the attrition rate of this OC. It was concluded that a Cu-based OC prepared using $\gamma \mathrm{Al}_{2} \mathrm{O}_{3}$ as support modified with a small $\mathrm{NiO}$ addition is adequate to operate without attrition or agglomeration problems in the CLC process at high temperature.

The initial values of the crushing strength of the OC particles are not a suitable characteristic to evaluate the particle lifetime in the process.

This is the first time that a Cu-based OC, prepared by a commercial manufacturing method, and used at $1173 \mathrm{~K}$ in the FR and $1223 \mathrm{~K}$ in the AR exhibits such a good properties: high reactivity together with high mechanical durability and absence of agglomeration. This result opens new possibilities for the application of Cu-based materials in industrial-scale CLC processes.

\section{Acknowledgements}

This research was conducted with financial support from the Spanish Ministry of Science and Innovation (MICINN, Project CTQ2007-64400) and C.S.I.C. (200480E619). Special thanks to the Group of Combustion and Gasification of the Instituto de Carboquímica for allowing me individual publication of this article.

\section{References}

Adánez, J., De Diego, L. F., García-Labiano, F., Gayán, P.; Abad, A. \& Palacios, J. M. (2004). Selection of oxygen carriers for chemical-looping combustion. Energy and Fuels 18 (2), 371-377.

Adánez, J., Gayán, P., Celaya, J., de Diego, L. F., García-Labiano, F. \& Abad, A. (2006a). Chemical looping combustion in a $10 \mathrm{~kW}$ th prototype using a $\mathrm{CuO} / \mathrm{A} 12 \mathrm{O} 3$ oxygen carrier: Effect of operating conditions on methane combustion. Industrial and Engineering Chemistry Research 45 (17), 6075-6080.

Adánez, J., García-Labiano, F., De Diego, L. F., Gayán, P., Celaya, J. \& Abad, A. (2006b). Nickel- copper oxygen carriers to reach zero $\mathrm{CO}$ and $\mathrm{H}_{2}$ emissions in chemical-looping combustion. Industrial and Engineering Chemistry Research 45 (8), 2617-2625.

Adánez, J., Dueso, C., de Diego, L. F., GarcíaLabiano, F., Gayán, P. \& Abad, A. (2009). Methane Combustion in a 500 Wth Chemical-Looping Combustion System Using an Impregnated NiBased Oxygen Carrier. Energy \& Fuels 23, 130-142.

Adánez, J., Abad, A., García-Labiano, F., Gayán, P. \& De Diego, L. F. (2012). Progress in ChemicalLooping Combustion and Reforming technologies. Progress in Energy and Combustion Science 38 (2), 215-282.

Artizzu, P., Garbowski, E., Primet, M., Brulle, Y. \& Saint-Just, J. (1999). Catalytic combustion of methane on aluminate-supported copper oxide. Catalysis Today 47 (1-4), 83-93.

Bolt, P. H., Habraken, F. H. P. M. \& Geus, J. W. (1998). Formation of nickel, cobalt, copper, and iron aluminates from a - and g-alumina-supported oxides: A comparative study. Journal of Solid State Chemistry 135 (1), 59-69.

Copeland, R. J., Alptekin, G., Cesario, M. \& Gershanovich, Y. (2002). Sorbent energy transfer system (SETS) for $\mathrm{CO}_{2}$ separation with high efficiency. In 27th International Technical Conference on Coal Utilization \& Fuel Systems, CTA: Clearwater, Florida, USA, March 4-7, Florida, USA, p 719-729.

Chuang, S. Y., Dennis, J. S., Hayhurst, A. N. \& Scott, S. A. (2008). Development and performance of $\mathrm{Cu}$-based oxygen carriers for chemical-looping combustion. Combustion and Flame 154 (1-2), 109-121.

Cho, P., Mattisson, T. \& Lyngfelt, A. (2004). Comparison of iron-, nickel-, copper- and manganese-based oxygen carriers for chemicallooping combustion. Fuel 83 (9), 1215-1225. 
De Diego, L. F., García-Labiano, F., Adánez, J., Gayán, P., Abad, A., Corbella, B. M. \& Palacios, J. M. (2004). Development of Cu-based oxygen carriers for chemical-looping combustion. Fuel 83 (13), 1749-1757.

De Diego, L. F., Gayán, P., García-Labiano, F., Celaya, J., Abad, A. \& Adánez, J. (2005). Impregnated $\mathrm{CuO} / \mathrm{Al} 2 \mathrm{O} 3$ oxygen carriers for chemical-looping combustion: Avoiding fluidized bed agglomeration. Energy and Fuels 19 (5), 18501856.

De Diego, L. F., García-Labiano, F., Gayán, P., Celaya, J., Palacios, J. M. \& Adánez, J. (2007). Operation of a $10 \mathrm{kWth}$ chemical-looping combustor during $200 \mathrm{~h}$ with a $\mathrm{CuO}-\mathrm{Al}_{2} \mathrm{O}_{3}$ oxygen carrier. Fuel 86 (7-8), 1036-1045.

Dueso, C., Abad, A., García-Labiano, F., de Diego, L. F., Gayán, P., Adánez, J. \& Lyngfelt, A. (2010). Reactivity of a $\mathrm{NiO} / \mathrm{Al}_{2} \mathrm{O}_{3}$ oxygen carrier prepared by impregnation for chemical-looping combustion. Fuel 89, 3399-3409.

Dueso, C., Ortiz, M., Abad, A., García-Labiano, F., de Diego, L.F., Gayán, P. \& Adánez, J. (2012). Reduction and oxidation kinetics of nickel-based oxygen-carriers for chemical-looping combustion and chemical-looping reforming. Chemical Engineering Journal 188 142-154.

Forero, C. R., Gayán, P., de Diego, L. F., Abad, A., García-Labiano, F. \& Adánez, J. (2009). Syngas combustion in a 500 Wth chemical-looping combustion system using an impregnated $\mathrm{Cu}$ based oxygen carrier. Fuel Processing Technology 90 (12), 1471-1479.

Forero, C. R., Gayán, P., García-Labiano, F., de Diego, L. F., Abad, A. \& Adánez, J. (2010). Effect of gas composition in chemical-looping combustion with copper-based oxygen carriers: fate of sulphur. International Journal of Greenhouse Gas Control 4 (5), 762-770.

Forero, C. R., Gayán, P., García-Labiano, F., de Diego, L. F., Abad, A. \& Adánez, J. (2011).
High temperature behaviour of a $\mathrm{CuO} / \gamma \mathrm{Al}_{2} \mathrm{O}_{3}$ oxygen carrier for chemical-looping combustion. International Journal of Grenhouse Gas Control 5, 659-667.

García-Labiano, F., Gayán, P., Adánez, J., de Diego, L. F. \& Forero, C. R. (2007). Solid waste management of a chemical-looping combustion plant using $\mathrm{Cu}-$ based oxygen carriers. Environmental Science and Technology 41 (16), 5882-5887.

Gayán, P.; Forero, C. R., de Diego, L. F., Abad, A., García-Labiano, F. \& Adánez, J. (2010). Effect of gas composition in chemical-looping combustion with copper-based oxygen carriers: fate of light hydrocarbons. International Journal of Greenhouse Gas Control 4 (1), 13-22.

Johansson, M., Mattisson, T. \& Lyngfelt, A. (2006). Comparison of oxygen carriers for chemicallooping combustion of methane-rich fuels. In 19th International Conference on Fluidized Bed Combustion, Vienna, Austria, May 21-24, Vienna, Austria, 2006.

Kerr, H. R. (2005). Capture and separation technology gaps and priority research needs. In Thomas, D.; Benson, S., Eds., Carbon Dioxide Capture for Storage in Deep Geologic FormationsResults from the $\mathrm{CO}_{2}$ Capture Project. Elsevier Science: Amsterdam, Vol. 1, p 655-660 (Chapter $38)$.

Kvamsdal, H. M., Jordal, K. \& Bolland, O. (2007). A quantitative comparison of gas turbine cycles with $\mathrm{CO}_{2}$ capture. Energy 32 (1), 10-24.

Li, C. \& Chen, Y.-W. (1995). Temperatureprogrammed-reduction studies of nickel oxide/ alumina catalysts: effects of the preparation method. Thermochimica Acta 256 (2), 457-465.

Luo, M.-F., Fang, P., He, M. \& Xie, Y.-L. (2005). In situ XRD, Raman, and TPR studies of $\mathrm{CuO} /$ A12O3 catalysts for $\mathrm{CO}$ oxidation. Journal of Molecular Catalysis A: Chemical 239 (1-2), 243248. 
Son, S. R., Go, K. S. \& Kim, S. D. (2009). Thermogravimetric analysis of copper oxide for chemical-looping hydrogen generation. Industrial \& Engineering Chemistry Research 48 (1), 380-387.
Susnitzky, D. \& Carter, B. (1991). The formation of copper aluminate by solid-state reaction. Journal of Materials Research 6, 1958-1963. 